\title{
Map and GIS database of glacial landforms and features related to the last British Ice Sheet
}

\author{
CHRIS D. CLARK, DAVID J.A. EVANS, ANJANA KHATWA, TOM BRADWELL, COLM J. \\ JORDAN, STUART H. MARSH, WISHART A. MITCHELL AND MARK D. BATEMAN \\ Clark, C.D., Evans, D.J.A., Khatwa, A., Bradwell, T., Jordan, C.J., Marsh, S.H., Mitchell, W.A. \\ \& Bateman, M.B: Map and GIS database of glacial landforms and features related to the last \\ British Ice Sheet.
}

A review of the academic literature and British Geological Survey mapping is employed to produce a 'Glacial Map', and accompanying geographic information system (GIS) database, of features related the last (Devensian) British Ice Sheet. The Map (1:625000) is included in a folder and GIS data is freely available by web download (http://www.shef.ac.uk/geography/staff/clark_chris/britice.html). Emphasis is on information that constrains the last ice sheet. The following are included: moraines, eskers, drumlins, meltwater channels, tunnel valleys, trimlines, limit of key glacigenic deposits, glaciolacustrine deposits, ice-dammed lakes, erratic dispersal patterns, shelf-edge fans, and the Loch Lomond Readvance limit of the main ice cap. The GIS contains over 20000 features split into thematic layers (as above). Individual features are attributed such that they can be traced back to their published sources. Given that the published sources of information that underpin this work were derived by a piecemeal effort over 150 years then our main caveat is of data consistency and reliability. It is hoped that this compilation will stimulate greater scrutiny of published data, assist in palaeo-glaciological reconstructions, and facilitate use of field-evidence in numerical ice sheet modelling. It may also help direct field workers in their future investigations.

Chris D. Clark (e-mail: c.clark@sheffield.ac.uk), Anjana Khatwa and Mark D. Bateman, Department of Geography, University of Sheffield, Sheffield, S10 2TN, UK; David J.A. Evans, Department of Geography and Topographic Science, University of Glasgow, Glasgow, G12 8QQ, UK; Tom Bradwell, British Geological Survey, Murchison House, West Mains Road, Edinburgh, EH9 3LA, UK; Colm J. Jordan and Stuart H. Marsh, British Geological Survey, Kingsley Dunham Centre, Keyworth, Nottingham, NG12 5GG, UK; Wishart A. Mitchell, Department of Geography, Science Site, South Road, Durham, DH1 3LE, UK. 
It has been known for over 150 years that large parts of Britain were inundated by an ice sheet during the last glaciation. Numerous investigations, primarily by field geologists of the British Geological Survey (formerly Institute of Geological Sciences) and by university-based academics, have yielded a plethora of publications reporting field evidence pertaining to the extent and dynamics of the last (Devensian) ice sheet. The information base is so large, likely exceeding 2000 publications, that all pieces of the jigsaw have never been assembled. This paper reports our attempt to do so. Information from published sources has been entered into a geographic information system (GIS) database, which was then summarised to produce the accompanying 'Glacial Map'. Whilst the database is large (>20000 individual features) and as complete as we have been able to make it, we wish to emphasise that it is not fully comprehensive. The rationale and scope regarding which features are included is outlined later. Also, we were forced to exclude some features because a number of published sources did not document the landforms and features with enough geographic information (e.g. grid references, positions of roads, rivers) to enable their transfer to the GIS, or were reproduced as schematic maps at too coarse a scale. If important features are missing it is for these practical reasons and not that we have made an academic judgment on their reliability.

Emphasis was placed on compilation of evidence that would help constrain the Devensian ice sheet, primarily its extent (e.g. moraines, 'drift limits', nunataks) and flow geometry (e.g. drumlins, erratic dispersal). Features from earlier and later glacial events (Anglian Glaciation, and Loch Lomond Readvance) are excluded, and it was impractical to include evidence for ice dynamics gleaned from investigation of stratigraphic sections. The compilation is thus primarily a geomorphological synthesis, incorporating landforms that inform us about the last ice sheet. The aim was to include evidence rather than interpretations, although it is recognised that the boundary between these is sometimes difficult to ascertain. As an example, we include drumlins as these are evidence for palaeo-ice flow direction, but ignore published interpretations of flow patterns.

Every attempt was made to investigate all relevant published papers, geological memoirs and maps, from which information was extracted, entered into a GIS, and organised into thematic layers. Data came from a variety of scales (typically 1:5000 - 1:50000) and were entered into the GIS at their full resolution. These data had to be generalised (smoothed or simplified) in order to produce the accompanying Glacial Map at a scale of 1:625000. 


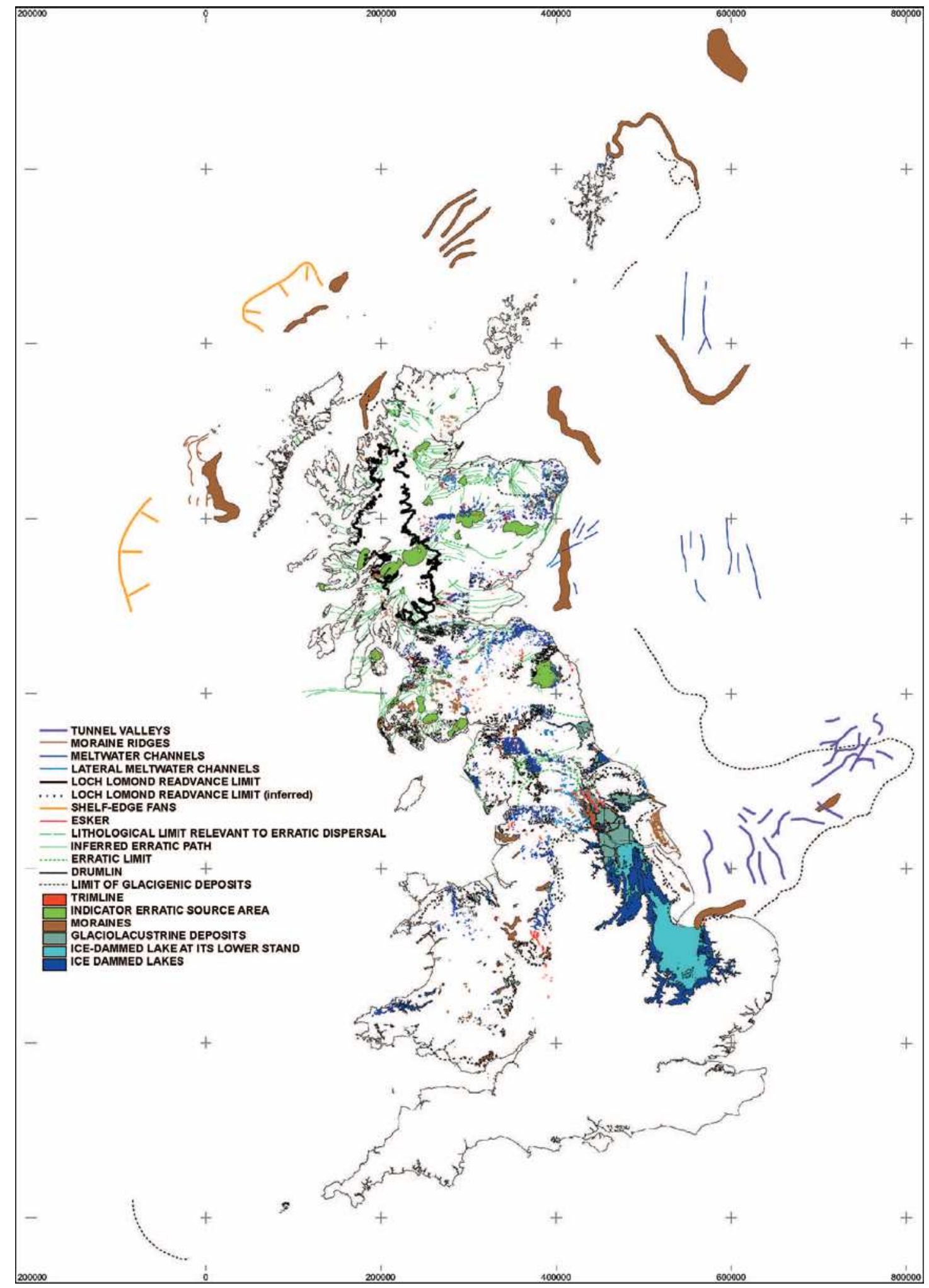

Figure 1. Overview of all twenty thematic layers displayed within the GIS including terrestrial and offshore features. The database comprises over 20,000 individual features split into thematic layers of moraines, eskers, drumlins, meltwater channels, tunnel valleys, shelf-edge fans, trimlines, limit of key glacigenic deposits ('drift limits'), glaciolacustrine deposits, ice dammed lakes, erratic dispersal, and the West Highland Loch Lomond Readvance limit.

This paper reports our methodology, and importantly, the main caveats that should be considered when using the map or GIS to make palaeoglaciological interpretations. The Glacial Map is 
contained in a folder accompanying this paper and the original GIS data layers (prior to generalisation) are freely available by download from a website (see below). A time-consuming element of this work has been to produce outputs in which the information can be traced back to original sources. This is important as the reliability of our map and GIS is entirely dependent upon the quality of the original mapping. For users of the map, the full bibliography of all sources utilised is available via the web page, but of greater utility are the GIS data layers. Once assembled in appropriate software (ESRI ArcMap®, Arcview ${ }^{\circledR}$, ArcInfo® or Erdas Imagine $\left.{ }^{\circledR}\right)$ they can be viewed at detailed map scales and it is possible to point the cursor at any individual feature whereupon the citation will be provided along with any qualifying comments.

\section{Evidence included and excluded}

It was not practical to include all evidence relating to the ice sheet as much of it does not lend itself to presentation in map form or GIS, and if the project had been too inclusive the task was unlikely to be completed. Guidance with regard to the type of evidence to include was sought from glacial maps from other countries such as the Glacial Map of Canada (Prest et al. 1968). The following information is included: moraines, eskers, drumlins, meltwater channels, tunnel valleys, shelf-edge fans, trimlines, limit of key glacigenic deposits ('drift limits'), glaciolacustrine deposits, ice-dammed lakes, erratic dispersal, and the Loch Lomond Readvance limit of the West Highland glacier complex. The details of these are described later. Figure 1 provides an overview of the data viewed within the GIS.

After pilot investigations to assess the volume and nature of the evidence it was decided to exclude a range of potentially useful evidence for the reasons outlined below. Glacial striae are of use in indicating local ice flow directions, particularly in predominantly bedrock areas where no other ice directional features are present. Large volumes of striae data exist on the unpublished 6-inch scale 'County Series' maps held by the British Geological Survey (BGS). Striae data however, were not seen as a high priority as they may not be reliable indicators of regional ice flow (cf. Kleman 1990; Clark et al. 2000; Rea et al. 2001, although see Veillette et al. 1999) and it soon became apparent that the volume of data made the task too large. Streamlined bedrock, roches moutonees and crag-and-tails also contain valuable ice-directional information, but were excluded because of the limited information on their distribution. Former marine limits and raised beaches were excluded due to time constraints. 
Numerous papers report data on till fabrics which, if reliably identified as of Devensian age could make a useful addition. However these were not included, because the data has been collected by a variety of methods, is of variable quality and has limited spatial coverage.

It was originally intended to include kames, but it became apparent that any data layer would be of little merit because the origin of these features is poorly defined and the nomenclature varies widely between authors and over time. Information on kames has thus been excluded. The same is true for hummocky moraine. After initially entering many areas of hummocky moraine we chose to exclude this category once numerous inconsistencies were discovered in the literature with respect to definitions and genetic interpretations.

Information on the spatial distribution of glacigenic deposits (surficial geology) has been excluded as it was beyond the scope of this project and would largely duplicate existing BGS mapping. The Quaternary Map of the United Kingdom (IGS 1977) was produced at the same scale as our Glacial Map (1:625000) and portrays the extent and distribution of key deposits such as 'boulder clay and morainic drift', 'raised beach and marine deposits' etc. However, it does not include landform information, and we expect that the two maps will be used in synergy.

\section{Literature and map investigation}

All information within the GIS and on the map is derived from published sources or from 'open files' within the BGS archive. We resisted adding or modifying data according to our own views and knowledge or those of others, as such information would be unverifiable. The academic literature, $\mathrm{PhD}$ theses, geological memoirs and geological maps were searched and investigated for relevant information. BGS maps and memoirs, including offshore volumes, were systematically examined. For the academic literature, relevant papers were sought by crossreferencing from other papers rather than a systematic search of all journals. Only selected $\mathrm{PhD}$ theses were used where they had been cross-referenced from other sources. Well in excess of 1000 sources have been examined, of which 638 were found to contain relevant and reproducible information. These are included in the GIS and are recorded in the full bibliography, available on the web page.

A further paper reviewing the literature used in the compilation of the Glacial Map of Britain will be forthcoming (Evans et al. in press). This will provide an assessment of individual research contributions; particularly those published in journals, and will be illustrated using digital elevation models (DEMs) that cover critical landform assemblages. Brief reference will 
also be made in that paper to the critical stratigraphic details and dating controls on the glacial landforms, although it is not first and foremost a morphostratigraphic exercise.

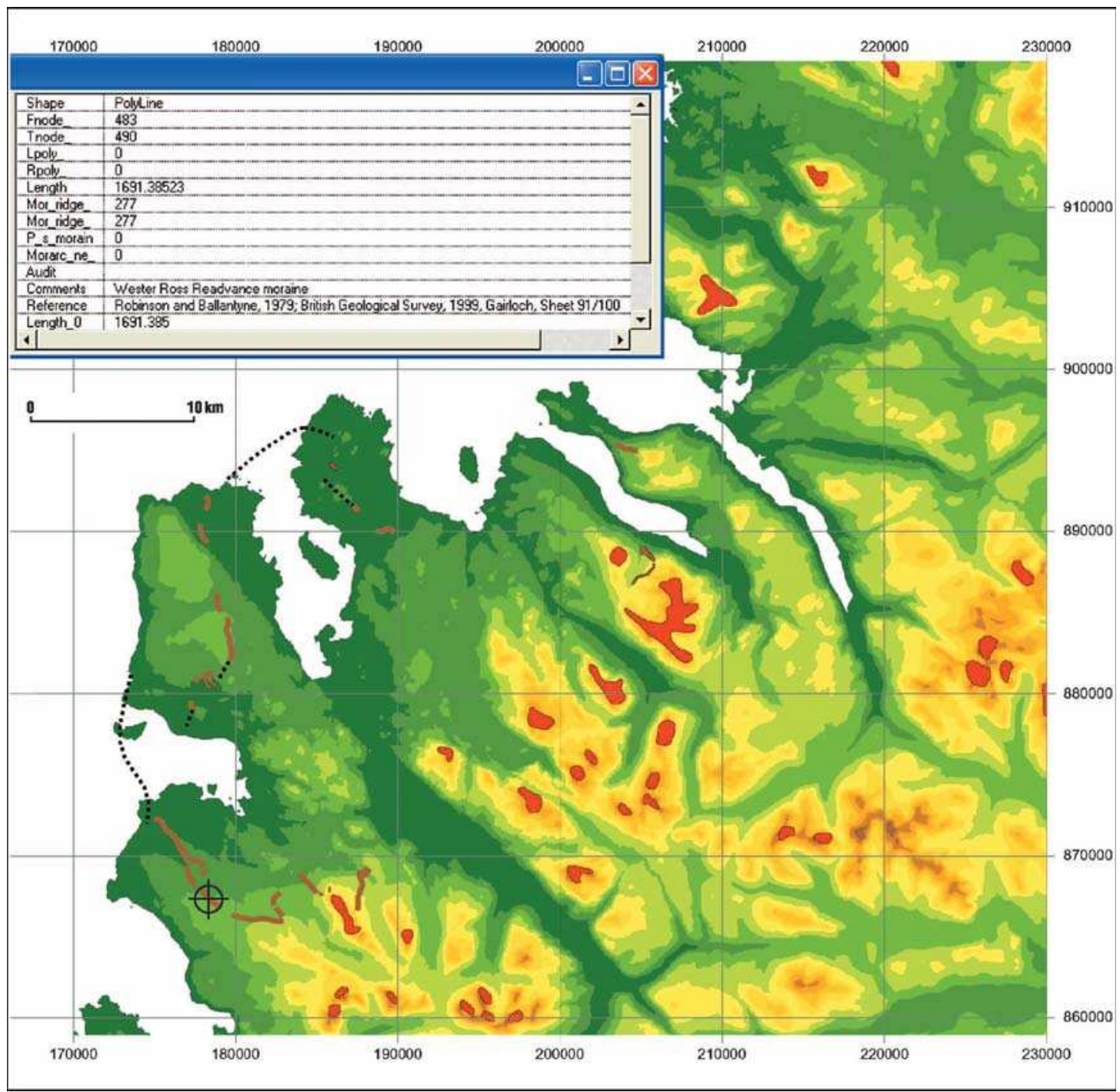

Figure 2. On-screen view of some of the GIS layers: trimlines (nunataks) in red, moraine ridges in brown and limit of glacigenic deposits in dashed black, overlaid on a DEM of topography for part of Wester Ross, Scotland. This illustrates how it is possible to interrogate any individual feature (see black target symbol) and receive information on the published source from where it derives and a brief explanatory comment.

The British Geological Survey archives a wealth of information on Quaternary mapping, much of which has not reached publication and remains on 'open file'. This information derives from the efforts of field geologists dating back to the $19^{\text {th }}$ century. Information was recorded on 'field slips' which was simplified as necessary and hand copied onto six-inch scale County Series maps (1:10560). These were again generalised to produce the published one-inch scale (1:63360) or 1:50000 maps. The process of generalisation is necessary for scale reduction and to make various map sheets match up across boundaries and to establish a systematic procedure between areas. The field slips and six-inch scale maps remain the primary document and are kept at the BGS and are available for consultation. We conducted a four-week pilot survey of one 
hundred Scottish six-inch scale County Series maps and concluded that they contained abundant relevant information that had not been included on published maps. This was especially so for drumlins, moraines and glaciofluvial features, but varied considerably dependent on the geologist who mapped them. Time constraints, however, made it impracticable to review these sheets for the whole of Britain and to assimilate all these data into the GIS. A compromise was reached whereby all published one-inch scale and 1:50000 sheets were examined, but for locations that seemed unusually sparse in glacial landforms (i.e. in contrast to an adjoining map sheet, or from comments in the geological memoir), the six-inch scale County Series maps were consulted and data was added accordingly. Such recourse to the more detailed mapping was only performed for Scotland.

We found that glacial landform data from the published BGS maps (One-inch and 1:50000) was variable in content. Although many sheets contain detailed information concerning the presence of drumlins, eskers, moraines, meltwater channels etc. (e.g. Denbigh Sheet (England and Wales) 107; Ayr Sheet (Scotland) 14W), these features were not consistently mapped on every sheet. The level of detail was often dependent on the type of map (e.g. drift only, solid and drift, solid with selected drift deposits); the age of the map ( $1^{\text {st }}$ series, $2^{\text {nd }}$ series, and provisional series); and whether the surveyor was experienced or interested in Quaternary mapping. Recently published/surveyed regions (especially those surveyed by Quaternary geologists) are richest in glacial landform data.

Data derived from the academic literature is patchy due to the fact that the Quaternary geomorphology of Britain has not been systematically mapped. Indeed, some areas seem to have received repeated attention whilst others remain unvisited. Further limitations exist due to the different terminology and mapping styles employed between different authors and over time. Nevertheless, the academic literature yielded data of similar volume and coverage to the BGS surveying.

Both sources of data contain inevitable problems with regard to compiling a consistent data set. One critical factor is that our understanding of glacial process - form relationships has evolved over time and the terminology has developed accordingly. We have used our informed judgement in these cases (see later), but if confusion arises recourse to the source publication is encouraged. 


\section{Data entry into GIS}

Information was manually digitised as lines (arcs) or areas (polygons) into thematic GIS layers (e.g. separate layers for eskers, moraines etc.) and stored as Arc Info 'coverages' and 'shapefiles'. The software packages Arc Info ${ }^{\circledR}$, Arcview $^{\circledR}$ and Erdas Imagine ${ }^{\circledR}$ were used to accomplish this. All layers are spatially registered to the British Ordnance Survey (OS) national grid system (modified Transverse Mercator). For each layer an attribute association was implemented such that each feature has an associated series of comments including the citation, indicating where the information was derived and a brief comment (Fig. 2).

A variety of methods of data input were employed. For large maps the easiest approach was to digitise via a digitising tablet, but for smaller maps or photocopies of maps from published papers, these were usually scanned to produce a raster graphics file (tiff), then converted to the file format used in Erdas ${ }^{\circledR}$, and geometrically corrected so that they conformed to the Ordnance Survey national grid system. Once loaded as an image in the Erdas® software the appropriate layer (coverage) was overlain and on-screen ('heads-up') digitising of the relevant features performed.

The most problematic part of the procedure was that of geometric correction. This is because maps reproduced in the academic literature frequently contain little information that helps constrain the location of the identified features. Maps with gridlines or tick marks of labelled OS grid coordinates presented no problem. However, this was rare, and we frequently had to compare what information was included on the maps (e.g. river or road patterns, contours, locations of villages or towns, etc) with OS maps in order to perform a geometric correction. The problem of insufficient geographic information and maps produced at too coarse a scale, has inevitably led to inaccuracies in the location of some of the features within the GIS. Great efforts were made to include data even though the map detail was often poor. Inevitably, some information was not entered as it seemed fruitless to do so for maps that were little more than 'sketches' with no geographic indicators.

A digital elevation model (DEM) was compiled for Britain (50 m cell size) derived from OS 1:50000 mapping, produced by mosaicing all 20 by $20 \mathrm{~km}$ data tiles (courtesy of Edina Digimap) to make a single file. This topographic information was used as a quality check on some of the layers. Overlaying of features such as moraines, meltwater channels or trimlines on the DEM permitted cases of mis-registration and other errors to be identified and corrected. Examples include nunataks which did not appear on summits as they should due to scale and quality 
limitations of the original published map. Sometimes moraines entered from published maps derived by fieldwork, appeared much more clearly on the enhanced DEM renditions (see below).

\section{GIS data layers}

Within the GIS there are twenty thematic layers and one layer depicting the present-day coastline (Fig. 1). The data recording glacial features comprises 18692 arcs and 1420 polygons making a total of 20112 individual features. For each thematic layer we report the nature of the information included, rationale of how it has been dealt with, and any problems of consistency or caveats regarding how they might be interpreted.

\section{Moraines}

We define moraines to include all ice-marginal accumulations of sediment with a topographic expression defining a distinct landform. They usually comprise glacial diamict, but in our definition we include ice-contact fans that contain fluvially deposited sand and gravel. The palaeoglaciological information they impart is that of a former ice margin position. Our liberal definition allowed us to include numerous ice marginal features whose exact depositional origin was ambiguous. Moraines are represented in the GIS by two layers: MORAINE includes the larger moraines, represented as areas (polygons) defining their extent and size, and 926 examples are included; MORAINE RIDGE includes smaller features or those for which published accounts only included a crestline, and are thus represented in the GIS as simple lines (arcs); there are 1264 examples of these.

This was the most difficult layer to compile. Simple data entry of all moraine information from publications often produced a rather contradictory and confusing result (e.g. Fig. 3A). This is mainly because authors have depicted moraines in a variety of styles, and there is a degree of subjective judgement in how moraines are defined. In the field, for example, moraines may occur as a single ridge with a distinctive crest, whereas others may comprise a zone of hummocks and ridges, with an indistinct outer boundary. Some publications just mark moraine crests, whilst others outline the break of slope bounding the overall landform. Furthermore, earlier use of the term 'moraine' was taken to include sheet-like spreads of till rather than a landform. In cases where we suspected this to be the case, recourse was made to the DEM to verify if there was any landform expression. Without a new and systematic mapping programme of all moraines it is impossible to overcome such inconsistencies. 

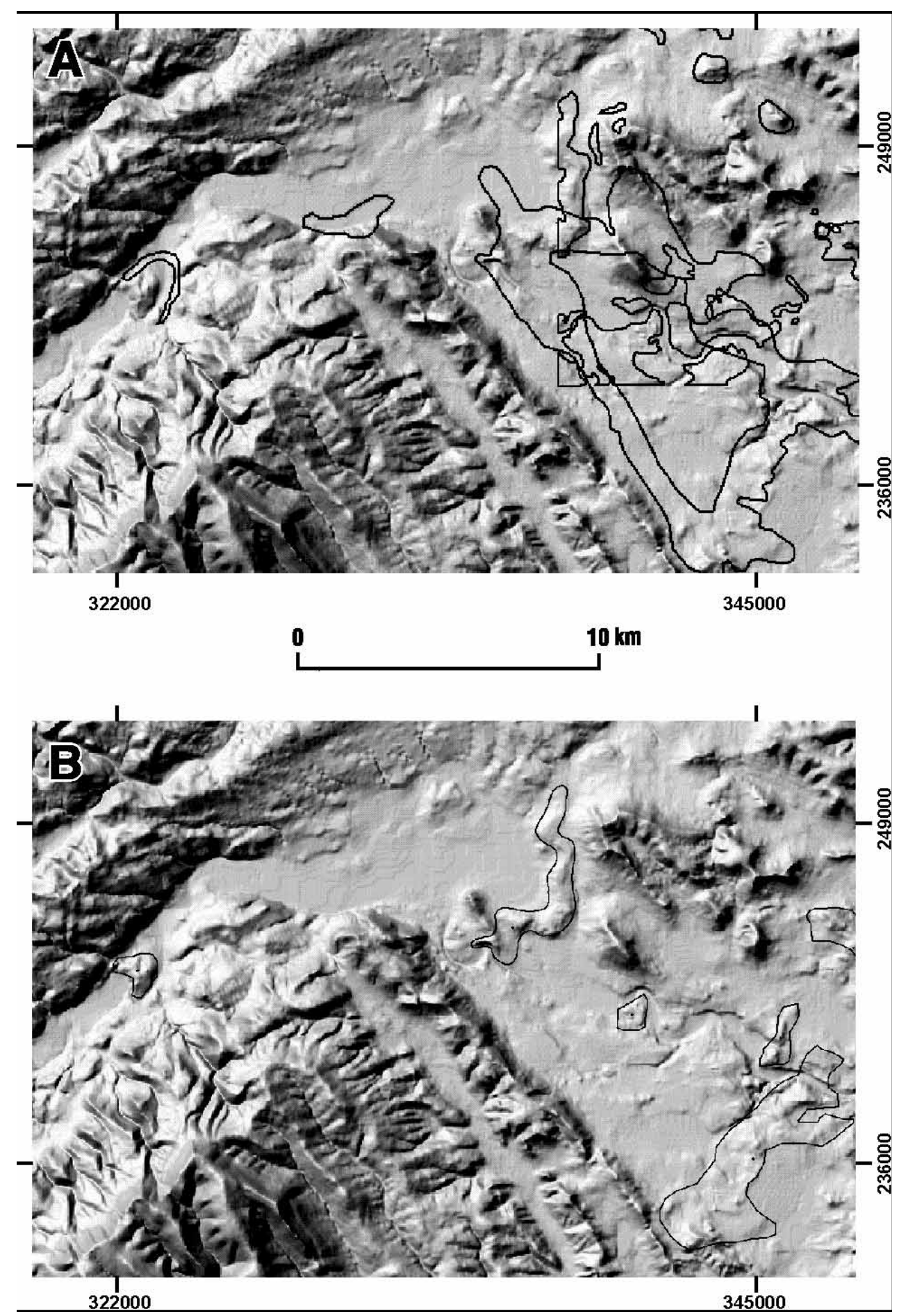

Figure 3. Given the subjectivity involved in mapping moraines and their varying definitions it is no surprise that contradictory versions are encountered. In (A) the results from a variety of sources are included and compared against topography from a shaded rendition of a DEM. For a small number of such incidents we modified the mapping $(B)$ to gain better accord with moraine expression obvious from the DEM. In such cases the original source reference is included in the GIS and a comment to the effect that some modification has been implemented. The examples shown are the Wye Valley and Hay end moraines.

Once all moraine features were digitised they were overlaid on shaded renditions of the DEM. By using both NW and NE shaded renditions it was possible to assess the degree to which any hypothesised moraine actually had a reliable topographic signature. Where conflicting depictions of the same moraine systems were reported in publications, the DEM visualisations were used to 
discriminate between them and decide which version to include and which to omit. The DEM was also used to modify the outline of some moraine systems as it was clear that their expression was clearer to trace using the DEM than by fieldwork alone (Fig. 3B). The resolution of the $\operatorname{DEM}(50 \mathrm{~m})$ limited this approach to quality control and modification to the larger features (i.e. many hundreds of metres in size), and all of the smaller examples remain unchecked. For a limited number of moraine systems we have included conflicting moraine mapping, which is apparent where an outer boundary of a moraine also contains numerous smaller polygons derived from the more conservative mapper (e.g. Fig. 4).

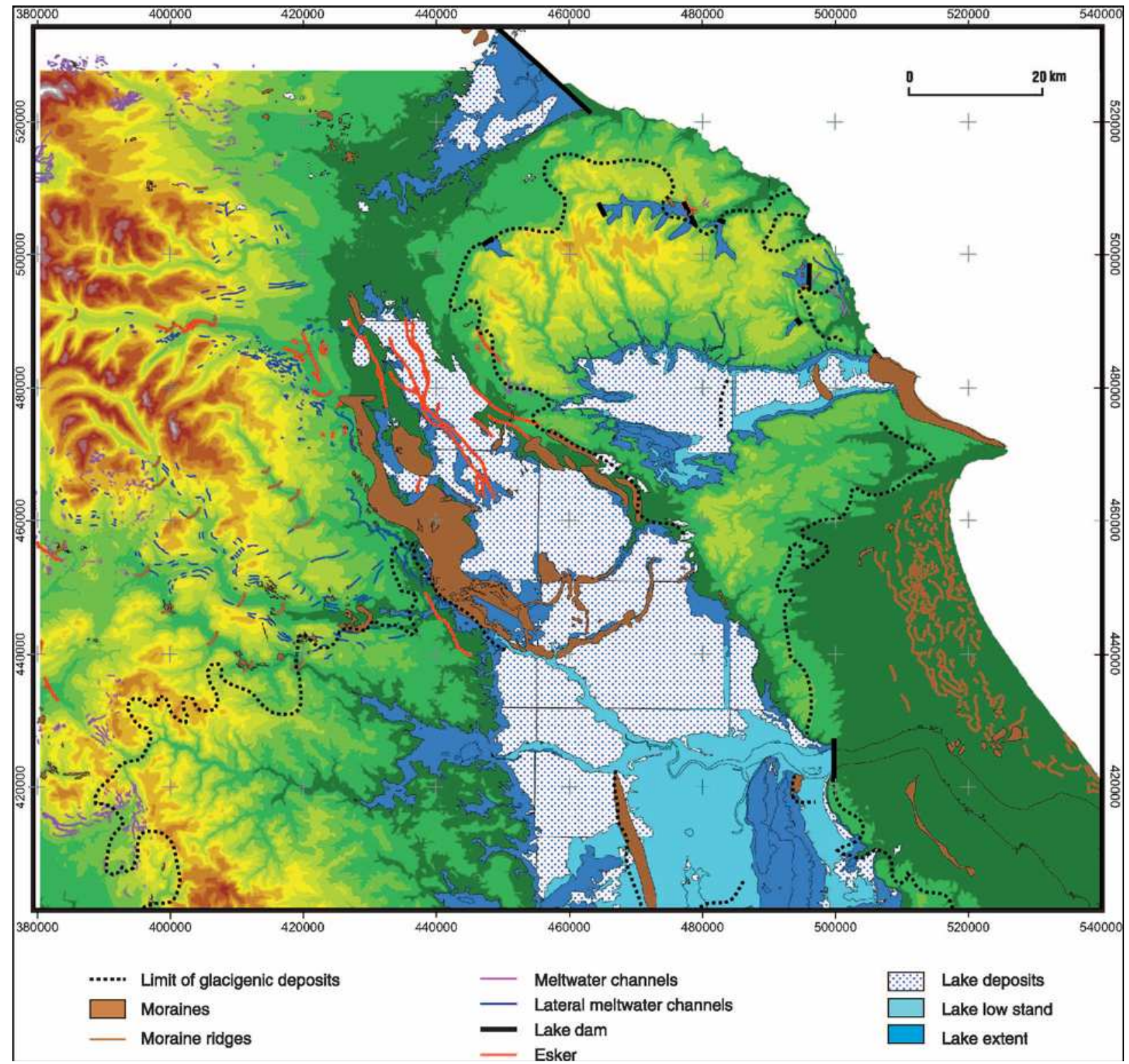

Figure 4. Example of the wealth of data displayed within the GIS for the Vale of York. Note that for the large YorkEscrick moraine (centre of the image) alternative versions of moraine representation are included (smaller polygons of the more conservative mapper within the larger polygon). 


\section{Eskers}

The academic literature and published maps contain coherent information on eskers that was relatively easy to compile. Within the GIS there is a single layer named ESKER which contains 857 arcs defining eskers and esker fragments. Although eskers are relatively easy to recognise and map, there is some conflict within the literature and alternative interpretations regarding eskers do exist. The 'Carstairs esker system' which has variously been interpreted as eskers, moraines, kames or as an ice-cored outwash fan (cf. Huddart \& Bennett 1997; Thomas \& Montague 1997) is a good example. Some of the older literature used terms such as 'Ossian mounds' or 'Ose-trains,' which are taken to be synonyms with eskers. Additionally, where we found published maps and papers indicating 'sand and gravel deposits' or 'glaciofluvial sediments' and where these lay in obvious linear fragments with evidence of tributaries (e.g. Hollingworth 1931), we interpreted them as eskers, even if the authors had not, and have entered them into the database as such, flagged with an appropriate comment.

\section{Drumlins}

The GIS contains a layer, DRUMLINS, each of which is represented by a single straight line along its long axis and in some cases, proportional to its length. There are 8350 drumlins in the database drawn from the academic literature and BGS mapping. No checking of these data or additions to the mapping has been performed although the possibility of doing so using satellite images and the DEM should prove fruitful and is underway (cf. Smith 2003). Great care should be exercised in interpreting drumlin lengths, patterns and densities between areas, as many of these differences arise from the mapping styles and generalisation methods employed by different authors. Most of the data record individual drumlins and their lengths (e.g. in Selkirkshire and Lanarkshire), but from some sources it was unclear as to whether the mapping actually represented drumlin long axes or whether it was a generalisation of the pattern in the area. For the area adjacent to the Lake District and western Pennines the drumlins in the database are not individual features but a generalisation of the pattern. The DRUMLIN layer could reasonably be used to reconstruct ice flow patterns and document the incidence of drumlin fields, but would not provide a reliable basis for analysing drumlin geomorphometry.

\section{Meltwater channels}

Published information reveals a large number of meltwater channels (>8000), but it is apparent from their distribution that their mapped coverage is patchy, with a high density of channels occurring in areas that have been mapped whilst large areas, often immediately adjacent, are 
devoid of channels (Fig. 5). It is unfeasible that the mapping presented here represents the true population of meltwater channels, and it is clear that much further investigation is required.

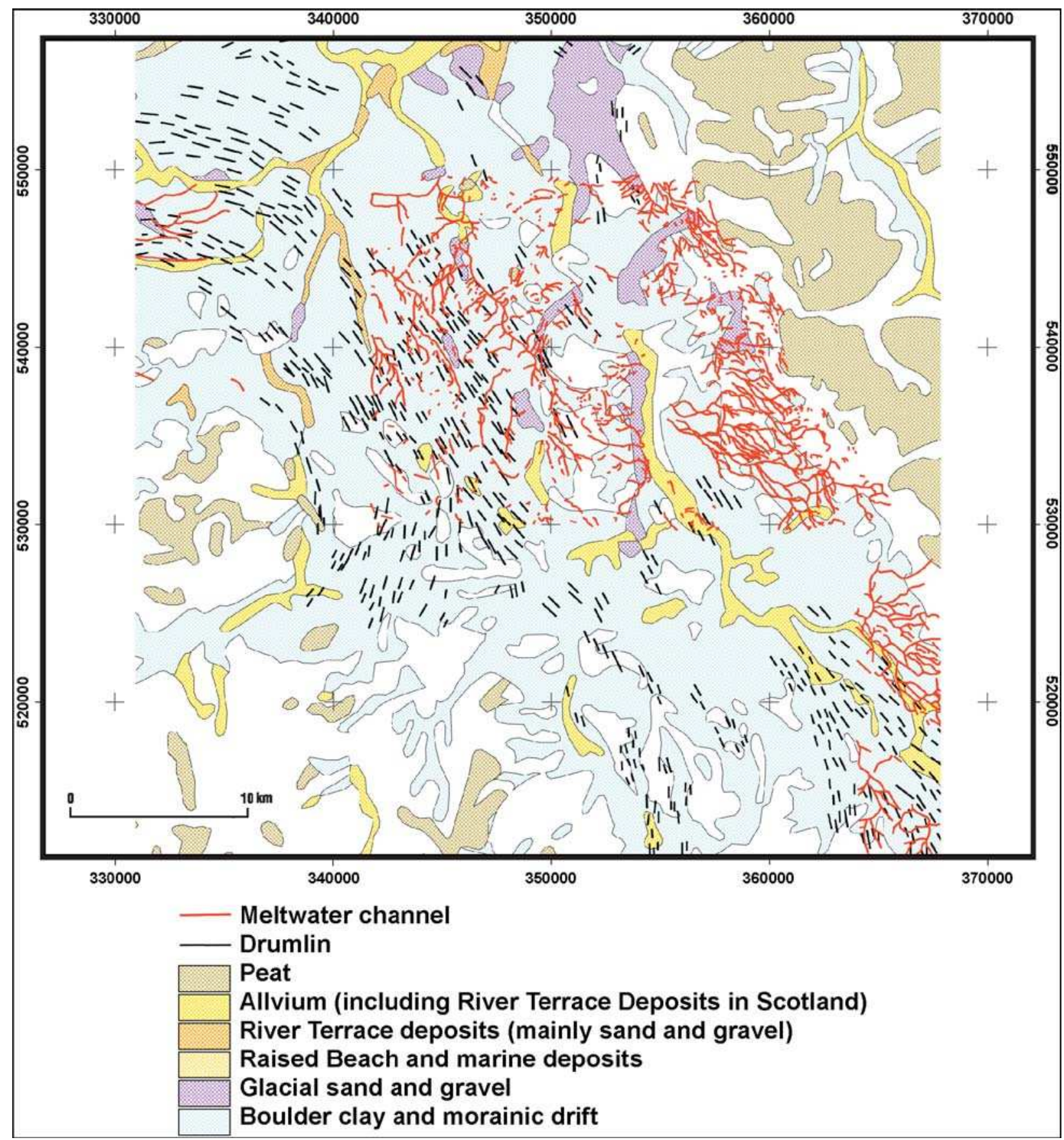

Figure 5. Example of how the GIS can be used to combine information from the GIS with the BGS digital version of the Quaternary Map of the United Kingdom (IGS 1977). Meltwater channels and drumlins from the GIS are seen overlaid on top of the BGS deposit mapping. Note the patch of high-density meltwater channels surrounded by an absence of data. This is an artefact of limited mapping rather than a reflection of the true population of meltwater channels. The area is around Penrith in the Vale of Eden.

Meltwater channels are created subglacially, ice-marginally or proglacially and it is important to distinguish between these in order to derive appropriate palaeoglaciological information. 
Well-defined subglacial channels (i.e. with humped long-profiles) inform us of ice presence, a warm-based thermal regime and disposition of the hydraulic head which can be used to approximate former ice-surface slope direction. Ice-marginal channels are formed in positions where the glacier edge meets a slope such as a valley flank. Rather than draining away from the glacier the topography forces water to flow along the margin cutting a channel into the landscape. We refer to these as lateral meltwater channels, and regard them as of great value for ice sheet reconstruction, as they record former ice marginal positions. The pattern of these channels in relation to the topography can be used to reconstruct retreat patterns of the ice margin (cf. Dyke 1993; Kleman 1992; Hättestrand 1998). Meltwater channels found on valley flanks or spurs that cut across the slope, bisecting contour lines at oblique angles, are good indicators that the channel was formed laterally. Proglacial channels are somewhat harder to define and separate from regularly formed, non-glacial, fluvial channels. The diagnostic features are that the channel size is much larger than the fluvial catchment could reasonably produce, or the incongruous position on, for example, a mountain col requires adjacent melting ice to be invoked. These are generally called spillways.

Unfortunately, although it is important to do so, it has often been difficult for field workers to reliably distinguish between different types of meltwater channel and so many features are simply mapped as generic meltwater channels. Initially, we intended to use the literature on meltwater channels and the relationships between features and their local topography to distinguish between the different types (subglacial, proglacial, lateral). However this proved unfeasible with current DEM resolutions, and the compromise adopted is as follows. Where authors have specifically argued and identified channels as having formed laterally we have entered them into a layer named LATERAL MELTWATER CHANNEL (1059 examples), but for all other cases they were entered into a generic MELTWATER CHANNEL layer (6949 examples). It is our assessment that although this layer mostly contains subglacial channels and some proglacial spillways, it also contains numerous lateral meltwater channels that require more work to demonstrate them to be so. An additional problem that became apparent was that some authors were more conservative than others in drawing the line between where a meltwater channel ends and a non-glacial fluvial channel starts. It is obvious that a channel cut by meltwater may eventually lead into proglacial fluvially-incised channels and hence the melt waters will discharge through them, but this does not make them meltwater channels in the sense that we use here. Knowing where to terminate the true meltwater channel is difficult and the choice made is somewhat arbitrary and different authors have done so with much variability. 


\section{Tunnel valleys}

Tunnel valleys are defined here as large subglacially cut meltwater channels. We report 22 examples beneath the North Sea which are contained in the TUNNEL VALLEY layer and derive from Balson \& Jeffrey (1991). It has been argued that 'enclosed deeps' (elongate, blind-ended, $100 \mathrm{~m}$ deep depressions in the bed of the North Sea) are also tunnel valleys eroded by jökulhlaups from huge subglacial lakes (Wingfield 1990). However, some controversy exists over the genesis of these features (Ehlers \& Wingfield 1991) and they have not been included in the database for this reason.

\section{Shelf-edge fans}

Two huge debris fans are included in the layer called FANS. These are the Barra Fan and Sula Sgeir Fan which lie on the slope of the continental shelf to the west of the Outer Hebrides (Stoker et al. 1993). They are major accumulations of sediment (over $1000 \mathrm{~m}$ thick) derived from erosion of the Scottish mainland during the late Tertiary and Quaternary. As such they are not solely Devensian glacial features but we include them because they contain large volumes of sediment exported from the last ice sheet, and must embody a valuable record with regard to sediment volumes and provenance, timing of glacial activity and ice rafted debris events.

\section{Trimlines}

Weathering limits (trimlines) that separate mountain summits with frost-weathered detritus from lower elevations with extensive ice scouring have recently been mapped for parts of Britain (e.g. Ballantyne et al. 1998). The inference commonly made is that many trimlines mark the upper limit of the last ice sheet, and therefore define palaeo-nunataks. If correct, trimlines provide important information on the vertical extent of the ice sheet and can be used to calculate thickness and volume estimates. However, alternative explanations for trimlines exist (cf. Ballantyne et al. 1998). Numerous authors attest that they represent boundaries between former warm and cold -based ice (Sugden 1968; Sugden \& Watts 1977; Kleman 1992; Kleman \& Borgström 1994; Clarhäll \& Kleman 1999) and hence cannot be used to define nunataks as the whole summit was covered by ice. Whichever inference is correct, it is clear that trimlines mark important glaciological boundaries and they are included for this reason (e.g. Fig. 2).

From the literature, 96 trimlines have been compiled and are marked as polygons on the appropriate mountain peaks of Scotland, England and Wales. We only included published assessments that included a map of their extent, excluding those that were just listed by summit name, as their extent was not defined. The positional accuracy of the polygons varies 
considerably depending upon the scale and geographic referencing of the source publications. The accuracy is relevant in this context, as when overlaid on a DEM or contour map, any slight horizontal displacement could give rise to large errors in elevation.

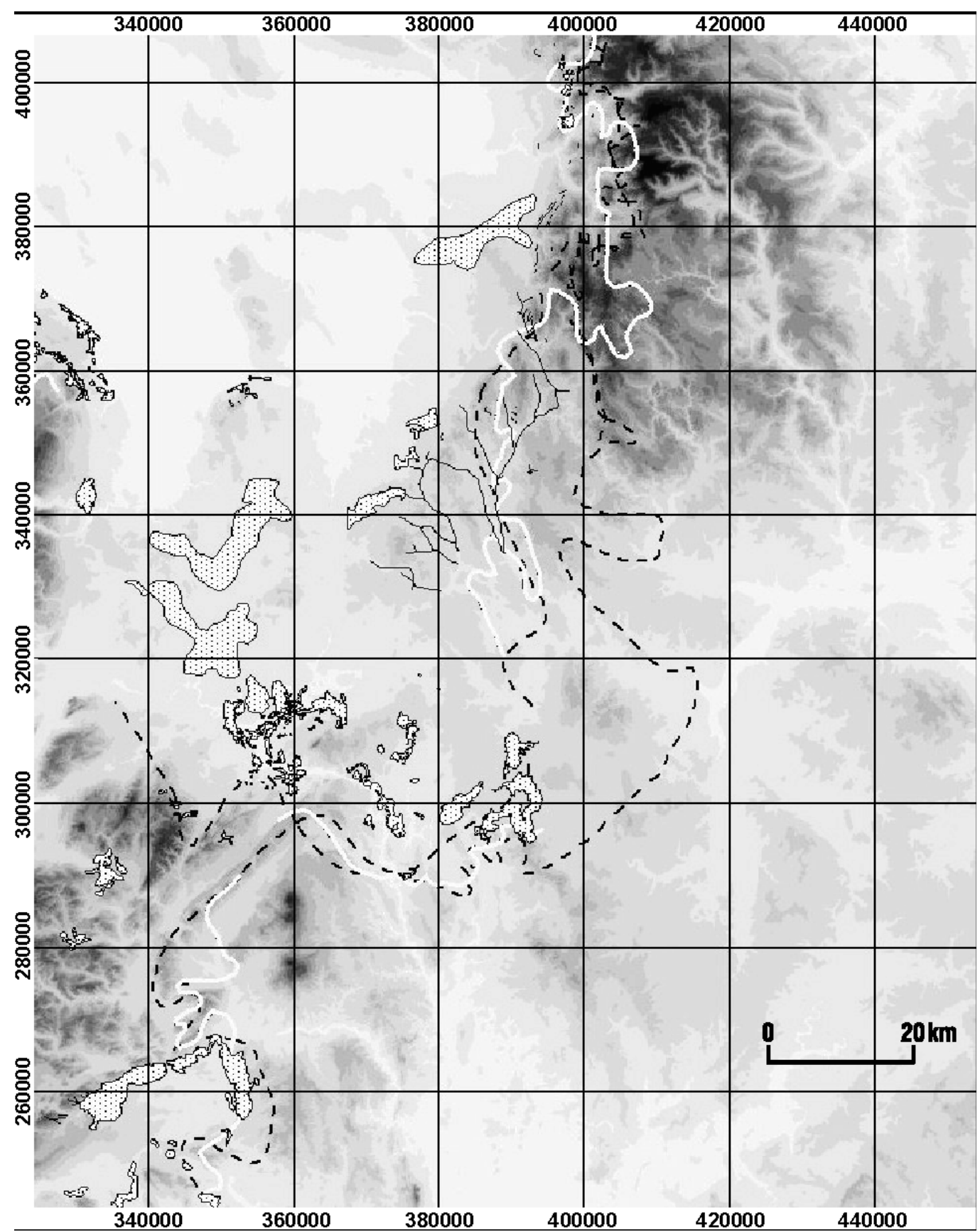

Figure 6. Selected GIS layers for a part of the Welsh Borders overlaid on DEM of topography, illustrating conflicting assessment of the limit of glacigenic deposits. Dashed black line indicates limits from a variety of authors including Gemmel \& George (1972), Worsley (1991), Brandon (1989), Catt (1991a, b), and Jowett \& Charlesworth (1929). Solid white line indicates the limit of glacigenic drift adopted in the GIS and map. Stippled polygons are moraines, and black lines are meltwater channels. 


\section{Limit of glacigenic deposits ('drift limits')}

Although this project has deliberately avoided duplicating information on the nature and distribution of glacial deposits (cf. BGS mapping and IGS 1977), we have included spatial limits of selected glacigenic deposits in cases where they are used to infer the extent of Devensian ice cover. For example, the southern limit of the British Ice Sheet has for a long time been based on the outermost limit to which glacial sediments are seen to extend (Clark et al. 2004). These are often termed 'drift limits'. Key glacigenic limits have been derived from the literature and are represented in the GIS and map by 44 lines (arcs). It has been common practice to use such limits to infer the maximum extent of Devensian ice cover, but we note three problematic issues. Firstly, it is clear that different investigators often mark the limits in different places (Fig. 6). This is unsurprising, as defining the limit of a deposit is subjective and different criteria are likely to have been used; the limit of thick diamict deposits, the line at which the deposits thin out significantly, or the furthest line at which any presence of glacial deposits can be detected. Secondly, as there are limitations in geochronometric dating it is often difficult to know if a specified limit definitely belongs to the Devensian. Finally, although widely adopted and perhaps reasonable, the limit of glacigenic deposits need not necessarily mark the true limit of ice cover. Ice may have advanced beyond these limits and simply not transported or deposited enough sediment to survive to the present day (e.g. Benn \& Evans 1998; chapter 12.3.2).

\section{Ice-dammed lakes}

As the ice sheet advanced and retreated across the landscape it impeded drainage of existing rivers along with glacial meltwater. The result was that numerous ice-dammed lakes were impounded. From the perspective of ice sheet reconstruction, glacial-lake evidence is invaluable as it is usually possible to infer the approximate position of the margin that is required to dam such a lake. This provides information on ice margin positions and retreat patterns. Numerous authors report laminated clays which they interpret as lake deposits. These sediments and their position in relation to local topography have led authors to infer the extent of former ice dammed lakes (e.g. Kendall 1902).

The overall objective of restricting the GIS database to evidence rather than interpretation is slightly relaxed for the case of ice-dammed lakes. Our motivation for this is because the position of ice-dams necessary for impounding lakes is extremely useful for reconstructing ice sheet configuration and retreat patterns. Rather than merely reporting the location of lake deposits, which helps little for an ice sheet wide reconstruction, we have included inferred lake extents as 
reported in the literature and have been forced in some cases to make interpretations regarding the extent of a few large and important lakes (e.g. Glacial Lake Humber) because such assessments are absent or too schematic in the literature. All such interpretations should be regarded as an hypothesis based on the fragmentary data.

From examination of all BGS maps, and papers in the academic literature, four layers are produced in the GIS and accompanying map. One identifies glaciolacustrine deposits, two layers record inferred lake extents, and a fourth layer illustrates likely lake-damming positions.

GLACIOLACUSTRINE DEPOSITS is a layer comprising 326 polygons which mark the location and extent of glaciolacustrine deposits, primarily from BGS maps, but with some drawn from the academic literature. All inliers and outliers have been excluded for the sake of simplicity, as have isolated lake deposits less than $0.5 \mathrm{~km}^{2}$. No cognisance has been taken of buried lake deposits under more recent deposits, e.g. the peat of Hatfield Moor, or deposits eroded away by the resumption of rivers, e.g. River Ouse. Published attribution of sediments to a lacustrine origin has been found to be variable due to the variety of workers, range of classification systems, and antiquity of mapping on some sheets. For example the sands and laminated clays of the Tyne-Wear Complex on BGS Sheet (England and Wales) 21 are clearly differentiated, mapped and attributed as being of lacustrine origin (Smith 1994). Conversely the '100-Foot' and '25-Foot' drifts for Lake Humber (Gaunt et al. 1992; Gaunt 1994) contain within them the generic category of sand and gravel some of which may relate to aeolian activity (e.g. BGS Selby Sheet (England and Wales) 71), or to marginal slope processes or leveés (e.g. BGS Kingston Upon Hull Sheet (England and Wales) 80). All units which are predominantly lacustrine are fully included and no attempt to exclude non-lacustrine components has been made. Whilst we have not been interested in mapping Quaternary deposits in general, we include lacustrine deposits as these are the key pieces of evidence to support the existence of former icedammed lakes. Within the GIS this layer remains unattributed, and users should refer to the appropriate BGS map sheets to find further information.

The geographic extent of ice-dammed lakes is included. For cases in which authors have reported evidence of lake deposits, and where they have reconstructed the lake level and inferred the lake extent, we have used the latter to map the approximate outline of the lakes. No attempt has been made to evaluate the quality or validity of the data upon which these lake extents have been inferred. Thus, for example, the work of Kendall (1903) in the Cleveland Hills shows numerous very detailed lake extents whilst other publications are more coy. 
The extent of larger lakes (Glacial Lakes Humber, Pickering, Tees and Weardale) has been inferred by taking published lake levels deduced from deposit elevations, limits, or geomorphological shoreline evidence, and extrapolating these across the DEM. This was necessary because, although published accounts widely report the lake levels, the lake outlines were never accurately plotted. For Lake Weardale, Smith (1994) reported a lake level of $43 \mathrm{~m}$ OD, which we use. For Lake Tees, Radge (1939) reported the level as 100 feet for which we have used $30 \mathrm{~m}$ OD. Two lake levels are widely found in the literature for Lake Pickering at 70 and $44 \mathrm{~m}$ OD and Lake Humber at 30 and 7 m OD (e.g. Straw 1979; Gaunt 1976, 1994). Two layers have been produced relating to inferred lake extents; LAKE EXTENT, which includes 22 polygons showing their inferred coverage, and LAKE LOW, which for the cases of Humber and Pickering, indicate the well known lower stands of these lakes.

From the disposition of glacial lakes in relation to topography, we have reproduced (from the literature), or deduced, where the approximate damming ice margin must have lain (layer; LAKE DAM). The actual position is not marked by field evidence, but merely indicates the approximate position and orientation required by an ice margin in order to impound the lake.

In principle, lake deposits should fall within the inferred lake limits. Within the GIS a good correspondence can be seen. This reassures us about the extrapolation procedure. However, some outliers do occur at the northern end of Glacial Lake Humber but we have not adjusted lake levels to include such deposits. Some of these deposits could be accounted for by contemporaneous glacioisostatic depression of the land and subsequent recovery but others are found at significantly higher elevations (e.g. Bugsthorpe Bottom, SK7757) and are likely to represent small ice dammed lakes separate to the main Lake Humber.

The dynamism and complexity of ice margins associated with ice-dammed lakes, especially those lakes formed as a result of more than one ice lobe, mean that some lakes may have been ephemeral and may not have filled their entire basins contemporaneously. The latter is especially valid for lakes extrapolated from lake levels. Likewise some lakes may have been partially subglacial, for example in the Vale of Pickering (Foster 1985). No account has been taken for glacioisostatic adjustment of the terrain and how this would have affected lake extents. 


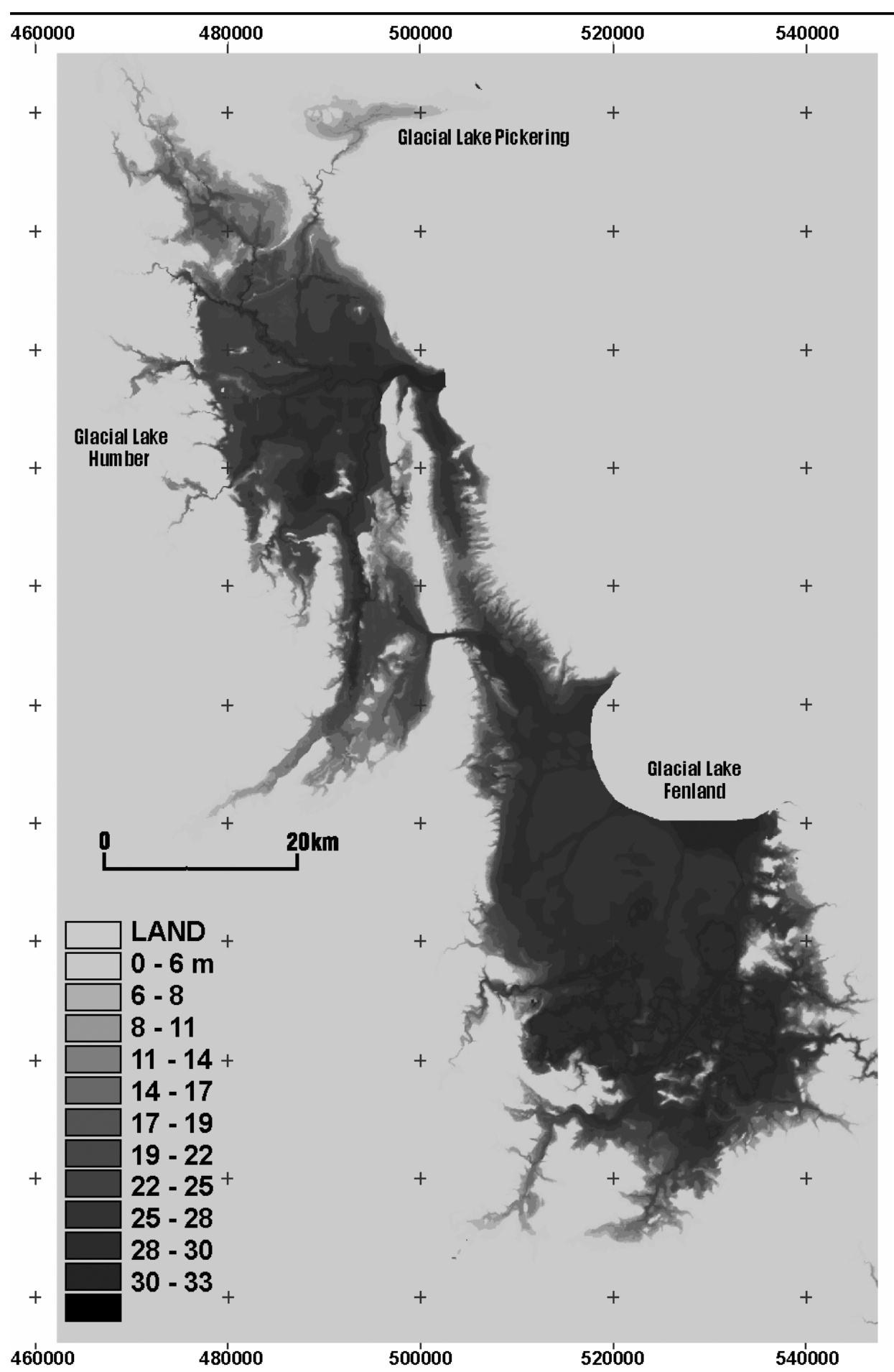

Figure 7. Extent and bathymetry of ice-dammed lakes Pickering, Humber and Fenland, as computed utilising published data on lake levels, ice damming positions and a DEM of topography. Note the overflows between the three lakes. Estimated lake volume of the combined system is $257 \mathrm{~km}^{3}$ with an average depth of around $20 \mathrm{~m}$. See text for details and caveats, especially with regard to the extent of Glacial Lake Fenland

A special cautionary note should be applied to Glacial Lake Fenland/Sparks (the large lake covering parts of Lincolnshire and East Anglia, e.g. Straw 1979; West 1993) which appears extensive when extrapolated via the DEM (Fig. 7) but has only limited evidence to support its existence. Harrod (1972) recorded a narrow bench at 25-32 m OD in slopes on the western 
margin of the fens around Horbling and Bourne in Lincolnshire, and lacustrine laminated clays at -2.0 to $1.3 \mathrm{~m}$ OD have been reported at Somersham, Cambridgeshire (West 1993; West et al. 1999). Our rationale for including this lake is based on a number of points. Firstly, if ice blocked the Wash Basin (as indicated by glacigenic limits and other evidence along the north Norfolk coast) then this ice lobe must have also blocked the Humber Gap at the same time. Glacial Lake Humber would have over-spilled through the Lincoln Gap, feeding southward flowing water into the Fen Basin, which along with existing drainage into the basin, would likely have caused extensive impounding of water forming the lake that we indicate. The exact maximal limit of this lake is entirely dependent on the efficiency of ice blocking the Fen basin, whether meltwater over-spilled across the East Anglian scarp, (e.g. Little Ouse/Waveney Valley gap (25 m OD) as suggested by Straw (1979)), and the duration of the ice-dam. Secondly, it is not possible for Lake Humber to have reached its highest stand unless water was prevented from escaping though the Lincoln gap, and given our first point above the easiest way to envisage this is for Lake Fenland to have existed. Alternatives would be an ice margin in the vicinity of the Lincoln Gap or that the gap was blocked by some other means. We appeal to the simplest argument, Lake Fenland, given that independent evidence for it exists. Finally, published evidence for lake sediments in the area exists (e.g. West 1993; West et al. 1999) and to our knowledge their findings have not been falsified, and a published estimate of the extent of Lake Fenland has been reported in Straw (1979). We note that West (1993) favoured a short-lived (sub-100 years) Lake Sparks (Fenland) which drained north along ice-marginal drainage paths. The limit shown for Lake Fenland assumes that it reached equilibrium with the high-level Lake Humber.

GIS analysis of the Glacial Lake Pickering - Humber - Fenland system was performed to estimate the lake bathymetry (Fig. 7) and volume. By combining the lake area with the underlying topography we estimate a volume of $257 \mathrm{~km}^{3}$, with a maximum depth of $31 \mathrm{~m}$ and average depth of $20 \mathrm{~m}$. These are underestimates, because Lake Humber largely infilled with sediment as demonstrated by the thick sequences of deposits present, and the DEM we used portrays present-day topography (i.e. includes these sediments).

\section{Erratic dispersal paths}

There is a large amount of published information reporting indicator erratic boulders and their areal dispersal. However, these data have been difficult to synthesise, largely because much of it is antiquated. Eminent local geologists led committees such as the 'Yorkshire Boulder Committee' which filed reports to the British Association (between 1873-1914) containing 
highly detailed accounts (e.g. Howarth 1908). Unfortunately, they are not in a form that makes regional compilation easy. It is common that reports of erratic boulders do not include sufficient geographical information (i.e. ' 12 miles southwest of the Red Lion') or do not include the source rock from which they came (i.e. 'erratic brought into the area from the north') or have varying classification schemes. Our attempt was somewhat thwarted by these problems and is therefore incomplete. A more thorough examination would be worthwhile and could include results from modern BGS geochemical anomaly surveying. Instead we rely heavily on regional compilations by Sutherland (1984) for Scotland, and by Howarth (1908) and Harmer (1928) for northern England, and add some other relevant information to compile layers on erratic pathways.

Erratic dispersal is marked using four layers, two to mark the spatial extents of the source rocks (INDICATOR ERRATIC SOURCE AREA; LITHOLOGICAL LIMIT RELEVANT TO ERRATIC DISPERSAL) one layer for the inferred pathway (INFERRED ERRATIC PATH), with the erratic find located at its arrowhead, and one layer to depict situations that mark the distal limit to which erratics are found (ERRATIC LIMIT). A total of 342 erratic pathways are included.

Care must be taken when using these data to reconstruct ice flow directions due to the nature of assumptions used in its composition. Firstly, the timing of transport is not known and is presumed to relate to the Devensian. The only actual evidence is the location of the erratic and the source rock from which it derives. The pathways are interpretative, in that they assume transport was by a single event rather than multiple phases (under varying ice flow directions) and the curves are drawn simply in correspondence to other localised information on flow direction, such as bedrock streamlining or striae. The pathways should thus be used with caution and we include them as a first estimate and as a guide in order to make the erratic data visible.

\section{Loch Lomond readvance ice limit}

We have attempted to exclude landforms relating to the ice caps and glaciers that existed during the Loch Lomond Stadial (13 - $11.5 \mathrm{ka}$ cal. BP). Without absolute dates, however, there may be some confusion as to whether landforms belong to the Dimlington or Loch Lomond Stadial. A layer (LOCH LOMOND READVANCE ICE LIMIT) is included as a method of explaining the absence of data within this part of West Scotland. Only the limit of the West Highland Glacier complex is presented, with smaller ice masses ignored. This limit was compiled from a variety of published sources and is shown by two layers, one where the limit is well defined and one for places where it has been inferred indirectly. 
Although there is a large literature on the glacial geomorphology and environmental reconstruction of the Loch Lomond Stadial, the limits of the West Highland Glacier Complex were compiled from a small number of recent sources that have provided summaries of glacier extent. Specifically, Thorp $(1986,1987,1991)$ provided details on the extent of the western Grampians glacier cover, including the southern lobes in Loch Lomond and the Teith valley. Details of the latter two sites are available in Rose (1981) and Evans (2003). Glacier margins in the Glen Roy/Glen Spean area were taken from Sissons (1979a). The reconstruction of Bennett \& Boulton (1993) was used for the northern Highlands and must be regarded as a maximum interpretation compared to previous publications. The limits in the southwest Highlands have proved to be problematic and several interpretations exist for the area; we used the limits of Sutherland (1981) in Loch Long and Loch Fyne areas and Sissons (1979b) around Loch Awe.

\section{Important caveats}

In addition to various comments in the preceding sections on the reliability and limitations of data, some general caveats apply. Only information that is published or data from BGS 'open files' has been included. We are likely to have missed some information or found it impractical to enter some material into the database. Given that the information included has not been derived by a systematic survey but by a piecemeal effort over 150 years by hundreds of different workers, then the main caveat is that of data consistency and reliability. We have not fieldchecked any of the features cited and merely report the details available in the published literature, with limited assessment against a DEM.

The locational accuracy of features is variable, and this should be borne in mind if locating features in the field. Errors are mostly due to inadequate geographic referencing in source maps. Most features are well positioned and with an accuracy of around $10 \mathrm{~m}$ possibly up to $50 \mathrm{~m}$, but for some features, particularly where the source maps contained poor geographic referencing, errors of hundreds of metres are possible. By referring to the cited source of information it will be obvious which features have been located with accuracy and which have not.

\section{Data generalisation for map production}

As data within the GIS is scale-independent it is possible to zoom in to a scale of 1: 10000 for example to see sufficient detail. The level of detail is dependent upon the scale and quality of the original map sources, coupled with our digitising precision. For map production, however, 
considerable generalisation and reduction of data was required in order for it to be reproduced at a scale of 1: 625000. When reproduced at this scale, features such as closely spaced meltwater channels, would appear as a dense blotch rather than as individual channels. In these cases generalisation was performed by selectively removing many channels until the spacing was suitable for cartographic reproduction. Some features appeared too crenulated and required smoothing, and other features were too small to be seen at the map scale. The GIS data layers were thus generalised for the purposes of map production by discarding unnecessary detail and smoothing some of the data. The original, un-generalised, GIS layers are available via web download.

\section{Context and motivation for compilation of the glacial map}

It is not the purpose of this paper to interpret the presented data or comment on the extent and dynamics of the ice sheet. Rather, we discuss the potential for further development of understanding of the British Ice Sheet, and the context in which this data-set may be used in achieving this. Reconstructions based on this and other data are in progress, and it is anticipated that others will use our compilation to advance knowledge of ice sheet geometry and dynamics.

In spite of more than a century of research and a voluminous published literature, only a modest amount is known about the flow configuration, thickness and dynamics of the British Ice Sheet. This is in contrast to the level of information available for other ice sheets such as the Laurentide and Fennoscandian, for which reconstructions of ice divide locations, flow patterns, ice margins and retreat patterns are available (e.g. Dyke \& Prest 1987; Clark et al. 2000; Kleman et al. 1997; Boulton et al. 2001). Most investigations of the British Ice Sheet have been on a local to regional basis which makes ice sheet wide synthesis difficult since differences in interpretation between areas remain unresolved. Reconstructions of the whole ice sheet geometry, based on available evidence, have rarely been attempted; indeed the generalised flow patterns put together by Charlesworth (1957) remain as the most complete synthesis. Numerical models of the ice sheet (e.g. Boulton et al. 1977, 1985) have been produced, but these display little of its dynamics.

The lack of synthesis or reconstruction, in spite of the volume of evidence, may be attributed to the complexity and scale of the task. Barriers to the production of a coherent description of the British Ice Sheet are considered to be; 
- The fragmented nature of the evidence, i.e. many spatially separate studies, with few links between them, large gaps, and many unresolved contradictions between areas.

- The volume of information. Paradoxically, it might be argued, there is too much evidence. There has been so much written and mapped that it is daunting to attempt a synthesis.

- Much of the data may be what Rhoads \& Thorn (1993) call "theory-laden evidence", i.e. as information has been collected over a long period of time, and during which glaciological ideas have changed considerably, it is likely that 'evidence' has been tainted by interpretations, some of which may no longer be valid. Some of the theory-laden evidence has likely propagated through the literature to add to the confusion.

- Contemporaneity of evidence. In seeking to reconstruct ice sheet geometry and extent based on the available evidence it is easiest and most convenient to assume that most evidence was formed penecontemporaneously as this provides maximum information about the ice sheet at a snapshot in time. However, this approach encourages contrived or unrealistic reconstructions, that can be falsified in places by evidence that does not match or by implausible ice dynamics. We presume that most evidence is likely to relate to the pattern of deglaciation with underlying palimpsests of maximal, or even build-up phases of ice sheet configuration. Recognition of these multi-temporal aspects and an 'inversion' methodology for making sense of it (Kleman \& Borgström 1996; Clark 1997) has led to advances in our understanding of other ice sheets, but has yet to be applied to the British Ice Sheet.

- Dating control. Much of the landform and stratigraphic evidence remains undated, and is thus difficult to fix in time and use in dynamic reconstructions.

- Incomplete mapping. Key parcels of information may not yet be identified and mapped which could unlock important parts of the glacial history.

The review and compilation of evidence presented here contributes to overcoming the first two points, and makes it significantly easier to address the other points. Much of the jigsaw puzzle is now assembled and we anticipate four main uses of the data:

- Evidence-based reconstruction of the ice sheet. Meltwater channels for example could be combined with the moraines, ice-dammed lakes, and eskers to build a sequential pattern of glacier retreat. The drumlin and erratic-pathway data could be analysed and enhanced by DEM and satellite mapping to derive the main ice flow patterns. These could be used to reconstruct changes in flow geometry and ice divide positions through time. Ideally a 
full inversion approach utilising all the data could be attempted and constrained by available stratigraphic and dating evidence.

- Numerical ice sheet modelling. Modelling has become increasingly important as an aid to reconstructing ice sheets and for assessing their relationship to other factors such as seasurface temperatures, climate, and sediment discharge (cf. Siegert 2001). Flow-pattern or ice margin-position information can be used to either drive the modelled reconstructions or as validations of the modelled result, or in some combination. As an example of the former, Boulton et al. (1977) utilised flow-pattern evidence to constrain the geometry of the British Ice Sheet and from this derived a modelled estimate of the surface topography. The opposite approach is to grow an ice sheet over the topography using climate drivers (i.e. derived from ice-core records) and then assess the plausibility of the modelled ice sheet by comparing ('testing') it with geomorphologically derived evidence of ice flow configuration and ice sheet margins. The modelling experiments of Marshall \& Clarke (1999) are an example of this approach but for the Laurentide Ice Sheet. It is frequent to hear field investigators criticise the work of ice sheet modellers because they sometimes fail to use the wealth of geological information available and because of a lack of proper testing of their results, against what is known. Such criticism is perhaps unfair given that evidence is so rarely compiled in a consistent form so as to make it of use. It is hoped that the GIS compilation presented in this paper will facilitate increased use of geomorphological data in modelling experiments.

- Directing fieldwork. It is evident from the Glacial Map that whilst there is a fairly good spread of information across the ice sheet bed, there are notable gaps and great variability in data density. Mid Wales, for example, is particularly sparse. This compilation may assist field workers in choosing future areas of investigation, mitigating the tendency within the academic community to keep re-investigating the same area.

- Contributing to BGS mapping programmes. Quaternary deposits cover a large proportion of Britain. Over the past 10 years there have been increasing requests for information to the BGS relating to the distribution and properties of these sediments. Consequently, there has been some refocusing of activities to concentrate on improving Quaternary mapping and understanding of superficial deposits (e.g. Foster et al. 1999, and reviewed by McMillan 2002). A major drive is also underway that has seen a move from paper map products to data in digital format (DigMapGB; BGS 1999), with the long term goal 
of producing a 3-D Geological Map of Great Britain. Our compilation of data is digital and is contributing directly to enhancing BGS digital archives of Quaternary data.

\section{Concluding remarks}

The data recorded on the glacial map and in the GIS database should not be viewed as a culmination of the jigsaw but as a stage that brings information together in order to stimulate further work and greater understanding. It should not be expected that all the pieces of information will fit together in a logical manner to yield a singular reconstruction of the ice sheet. Conflicts and discrepancies exist (e.g. eskers beyond the supposed ice limit) and some confusion is likely to exist with regard to the true age of some of the features (Pre-Devensian, Loch Lomond Stadial?). It is hoped that, in addition to the bulleted points in the preceding section, this work may encourage much greater scrutiny of valuable published work.

It is inevitable that some of the information may be incorrect and require rejecting or revising. Additionally, we have likely missed some important aspects. If material is not included it might be because the information was not presented in map form, the mapping was of insufficient quality (with regard to geographic referencing), it did not fit our target layers, it conflicted with other, perhaps better mapped data on the same feature, or we simply did not find the relevant publication. The intention is that the GIS will be periodically updated to include newly published information, and for revisions where found necessary. We therefore appeal for extra information, criticisms or suggested amendments. Please direct these to the lead author who will ensure that they are considered for the next update of the GIS. It should be noted that data is restricted to published information (including $\mathrm{PhD}$ theses) which provides a crude quality control and more importantly ensures that all data can be traced back to more detailed descriptions and observations.

It became apparent from our review of the academic literature that many publications contain maps of insufficient quality with regard to geographic referencing, making our task of ingestion into a GIS difficult. This form of reporting is not good practice, given that the idea of publication is to provide enough information to guide others to the phenomena of interest for critical examination. It is not sufficient to provide a map of the features and include a few rivers or town names as an indicator of their approximate location. It is recommended that labelled OS tick marks or grids should be included, and contrary to some views, there is no copyright problem with reproducing the national grid. We plea to authors, referees and journal editors to ensure that information is presented in an appropriate form. 
Dissemination of the data contained in the GIS is at no cost. All the GIS data layers, a graphics file (adobe® pdf) of the glacial map and full bibliography are available by download from a website hosted by the lead author (http://www.shef.ac.uk/geography/staff/clark_chris/britice.html) or via the BGS web pages. It is intended that updates and revisions to the database will be released by this mechanism. The data layers are provided in 'shapefile' format (produced in Erdas Imagine ${ }^{\circledR}$ version 8.5 and ArcView ${ }^{\circledR}$ version 3.2), and are easily loaded into ArcGIS®, Arc View ${ }^{\circledR}$ and Erdas Imagine ${ }^{\circledR}$ and are importable into other GIS or CAD software packages. The DEM used in some of the analysis is not available from the above website, but can be purchased from the Ordnance Survey, or for academic users can be obtained via Edina Digimap/JISC. A digital version of the Quaternary Map of the United Kingdom (a map of Quaternary deposits at 1:625,000 scale, IGS 1977: Fig. 5), is also available as 'shapefiles' from the BGS.

Future development of the GIS database may include layers pertaining to the Loch Lomond Stadial or the Anglian Glaciation. Additionally it may include more thematic layers such as glacial striae, hummocky moraines, periglacial and aeolian information.

Acknowledgements.- We acknowledge the British Geological Survey for partly funding the BRITICE project under their University Collaboration Advisory Committee. Neal Salomon and Lisa Collings are thanked for their work digitising some of the features, Steve Wise for GIS advice, and Graham Allsop for cartographic production of the map. Ordnance Survey digital elevation data and digital topographic maps were utilised courtesy of Edina Digimap/JISC. Bartholomew's is acknowledged for allowing us to reproduce their coastline data. The paper is published with permission of the Executive Director, BGS. The editor, Jan Piotrowski is thanked for entertaining the idea of a publication including such a large map. Jurgen Ehlers and Colin Whiteman provided helpful comments that have improved the manuscript and GIS compilation. 


\section{References}

The complete reference list (638 entries) of all sources used in compilation of the map and GIS is too large to reproduce here. It can be accessed at the web address http://www.shef.ac.uk/geography/staff/clark_chris/britice.html or via the GIS data.

Ballantyne, C. K., McCarroll, D., Nesje, A., Dahl, S. O. \& Stone, J. O. 1998: The last ice sheet in north-west Scotland: Reconstruction and implications. Quaternary Science Reviews 17, 1149-1184.

Balson, S. \& Jeffery, D. H. 1991: The glacial sequence of the southern North Sea. In Ehlers, J., Gibbard, P. L. \& Rose, J. (eds.): Glacial deposits in Great Britain and Ireland, 245- 254. Balkema, Rotterdam.

Benn D.I. \& Evans D.J.A. 1998: Glaciers and Glaciation. 734 pp. Arnold, London.

Bennett, M.R. \& Boulton, G.S. 1993: Deglaciation of the Younger Dryas or Loch Lomond Stadial icefield in the northern Highlands, Scotland. Journal of Quaternary Science 8, 133145.

BGS (British Geological Survey) 1999: Annual report of the British Geological Survey 19981999. 35 pp. Natural Environment Research Council, Swindon, Wiltshire.

Boulton, G. S., Jones, A. S., Clayton, K.M. \& Kenning, M.J. 1977: A British ice-sheet model and patterns of glacial erosion and deposition in Britain. In Shotton, F. W. (ed.): British Quaternary Studies, Recent Advances, 231-246. Clarendon Press, Oxford.

Boulton, G.S., Smith, G.D., Jones, A.S. \& Newsome, J. 1985: Glacial geology and glaciology of the last mid-latitude ice sheets. Journal of Geological Society of London 142, 447-474.

Boulton, G.S., Dongelmans, P., Punkari, M. \& Broadgate, M. 2001: Palaeoglaciology of an ice sheet through a glacial cycle: the European Ice Sheet through the Weichselian. Quaternary Science Reviews 20, 591-625.

Charlesworth, J. K. 1957: The Quaternary Era. 1700 pp. Arnold, London.

Clarhäll, A. \& Kleman, J. 1999: Distribution and glaciological implications of relict surfaces on the Ultevis plateau, northwestern Sweden. Annals of Glaciology, 28, 202-208.

Clark, C.D. 1997: Reconstructing the evolutionary dynamics of former ice sheets using multitemporal evidence, remote sensing and GIS. Quaternary Science Reviews 16, 1067 - 1092

Clark, C.D., Knight, J.K. \& Gray, J.T. 2000: Geomorphological reconstruction of the Labrador Sector of the Laurentide Ice Sheet. Quaternary Science Reviews 19, 1343-1366.

Clark, C.D., Gibbard, P.L. \& Rose, J. 2004: Pleistocene glacial limits in England, Scotland and Wales. In Ehlers, J. and Gibbard, P.L. (eds.): Quaternary Glaciations: Extent and Chronology, Part I; Europe. Developments in Quaternary Science. Elsevier.

Dyke, A.S. 1993: Landscapes of cold-centred Late Wisconsinan ice caps. Progress in Physical Geography 17, 223-247.

Dyke, A.S. \& Prest, V.K. 1987: Late Wisconsinan and Holocene history of the Laurentide Ice Sheet. Géographie Physique et Quaternaire 41, 237- 263.

Ehlers, J. \& Wingfield, R. 1991: The extension of the Late Weichselian/Late Devensian ice sheets in the North Sea basin. Journal of Quaternary Science 6, 313-326.

Evans, D.J.A., Clark, C.D. \& Mitchell, W.A. (in press). The last British Ice Sheet: a review of the evidence utilised in the compilation of the Glacial Map of Britain. Earth Science Reviews.

Evans, D. J. A. (ed.) 2003: The Quaternary of the Western Highland Boundary - Field Guide. 218pp. Quaternary Research association, London.

Foster S.W. 1985: The Late Glacial and Post Glacial History of the Vale of Pickering and Northern Yorkshire Wolds. Unpublished PhD thesis, University of Hull.

Foster, S.S.D., Morigi, A.N. \& Browne, M.A.E. 1999: Quaternary geology-towards meeting user requirements. 42 pp. British Geological Survey, Nottingham. 
Gaunt, G. D. 1976: The Devensian maximum ice limit in the Vale of York. Proceedings of the Yorkshire Geological Society 40, 631-637.

Gaunt, G. D. 1994: Geology of the country around Goole, Doncaster and the Isle of Axholme. 169 pp. Memoir of the British Geological Survey. HMSO, London.

Gaunt, G. D., Fletcher, T. P. \& Wood, C.J. 1992: Geology of the country around Kingston upon Hull and Brigg. 172 pp. Memoir of the British Geological Survey. HMSO, London.

Harmer, F.W. 1928: The distribution of erratics and drift. Proceedings of the Yorkshire Geological Society 21, 79-150.

Harrod, T.R. 1972: An investigation of major events in the geomorphological evolution of south and central Kesteven. $350 \mathrm{pp}$. Unpublished $\mathrm{PhD}$ thesis, University of Sheffield.

Hättestrand, C. 1998: The glacial geomorphology of central and northern Sweden. Sveriges Geologiska Undersökningar Serie Ca 85.

Hollingworth, S. E. 1931: Glaciation of western Edenside and adjoining areas and the drumlins of the Edenside and Solway Basin. Quarterly Journal of the Geological Society of London 87, 281-359.

Howarth, J. H. 1908: The ice-borne boulders of Yorkshire. The Naturalist March, 97-109.

Huddart, D. \& Bennett, M. R. 1997: The Carstairs Kames (Lanarkshire, Scotland): morphology, sedimentology and formation. Journal of Quaternary Science 12, 467-484.

Institute of Geological Sciences, 1977: Quaternary Map of the United Kingdom. Institute of Geological Sciences, Map at 1:625,000 scale. HMSO, London.

Kendall, P. F. 1902: Glacier-Lakes in the Cleveland Hills. Quarterly Journal of the Geological Society lviii, 471-571.

Kendall, P. F. 1903: The glacier Lakes of Cleveland. Proceedings of the Yorkshire Geological Society 15, 1-40.

Kleman, J. 1990: On the use of glacial striae for reconstruction of paleo-ice sheet flow patterns. Geografiska Annaler 72A, 217-236.

Kleman, J. 1992: The palimpsest glacial landscape in north-western Sweden- Late Weichselian deglaciation forms and traces of older west-centred ice sheets. Geografiska Annaler 74A, 305325 ,

Kleman, J. \& Borgström, I. 1996: Reconstruction of palaeo-ice sheets: the use of geomorphological data. Earth Surface Processes and Landforms 21, 893-909.

Kleman, J., Hättestrand, C., Borgström, I. \& Stroeven, A. 1997: Fennoscandian palaeoglaciology reconstructed using a glacial geological inversion model. Journal of Glaciology 43, 283-299.

Marshall, S.J. \& Clarke, G.K.C. 1999: Modeling North American freshwater runoff through the last glacial cycle. Quaternary Research 52, 300-315.

McMillan, A.A. 2002: Onshore Quaternary geological surveys in the $21^{\text {st }}$ century - a perspective from the British Geological Survey. Quaternary Science Reviews 21, 889-899.

Prest, V.K., Grant, D.R. \& Rampton, V.N. 1968: Glacial map of Canada. Geological Survey of Canada. Map 1253A.

Radge, G.W. 1939: The glaciation of North Clevedon. Proceedings of the Yorkshire Geology Society 24, $180-205$.

Rea, B.R., Evans, D.J.A., Dixon, T.S. \& Whalley, W.B. 2000: Contemporaneous, localized, basal ice-flow variations: implications for bedrock erosion and the origin of p-forms. Journal of Glaciology 46, 470-476.

Rhoads, B. L. \& Thorn, C. E. 1993: Geomorphology as science: the role of theory. Geomorphology 6, 287-307.

Rose, J. 1981: Field guide to the Quaternary geology of the southeastern part of the Loch Lomond basin. Proceedings of the Geological Society of Glasgow 123, 12-28. 
Siegert, M.J. 2001: Ice sheets and Late Quaternary environmental change. 231 pp. Wiley and sons, Chichester, England,

Sissons, J. B. 1979a: The limit of the Loch Lomond Advance in Glen Roy and vicinity. Scottish Journal of Geology 15, 31-42.

Sissons, J. B. 1979b: The Loch Lomond Stadial in the British Isles. Nature 280, 198-203.

Smith, D. B. 1994: Geology of the country around Sunderland. $161 \mathrm{pp}$. Memoir of the British Geological Survey. HMSO, London.

Smith, M.J. 2003: Techniques for the geomorphological reconstruction of palaeo ice sheets from remotely sensed data. $292 \mathrm{pp}$. Unpublished $\mathrm{PhD}$ thesis, University of Sheffield.

Stoker, M. S., Hitchen, K. \& Graham, C. C. 1993: UK offshore regional report: The geology of the Hebrides and the West Shetland shelves and adjacent deep water areas. $149 \mathrm{pp}$. British Geological Survey. HMSO, London.

Straw, A. 1979: The Devensian glaciation. In Straw, A., \& Clayton, K. M. (eds.): The geomorphology of the British Isles: Eastern and Central England. 21-45 pp. Methuen, London.

Sugden, D.E. 1968: The selectivity of glacial erosion in the Cairngorm Mountains, Scotland. Transactions of the Institute of British Geographers 45, 79-92.

Sugden, D.E. \& Watts, S.H. 1977: Tors, felsenmeer, and glaciation in northern Cumberland Peninsula, Baffin Island. Canadian Journal of Earth Sciences 14, 2817-2823.

Sutherland, D. G. 1981: The rasied shorelines and deglaciation of the Loch Long / Fyne area, Western Scotland. 460 pp. Unpublished PhD Thesis, Univeristy of Edinburgh.

Sutherland, D. G. 1984: The Quaternary deposits and landforms of Scotland and the neighbouring shelves: a review. Quaternary Science Reviews 3, 157-254.

Thomas, G. S. P. \& Montague, E. 1997: The morphology, stratigraphy and sedimentology of the Carstairs Esker, Scotland, U.K. Quaternary Science Reviews 16, 661-674.

Thorp, P.W. 1986: A mountain icefield of Loch Lomond Stadial age, western Grampians, Scotland. Boreas 15, 83-97.

Thorp, P.W. 1987: Late Devensian ice sheet in the western Grampians, Scotland. Journal of Quaternary Science 2, 103-112.

Thorp, P.W. 1991: Surface profiles and basal shear stresses of outlet glaciers from a Lateglacial mountain icefield in western Scotland. Journal of Glaciology 37, 77-88.

Veillete, J.J., Dyke, A.S. \& Roy, M. 1999: Ice-flow evolution of the Labrador Sector of the Laurentide Ice Sheet: a review, with new evidence from northern Quebec. Quaternary Science Reviews 18, 993-1019.

West, R.G. 1993: On the history of the Late Devensian Lake Sparks in southern Fenland, Cambridgeshire, England. Journal of Quaternary Science 8, 217-234.

West, R.G., Andrew, R., Catt, J.A., Hart, C.P., Hollin, J.T., Knudsen, K.-L., Miller, G.F., Penney, D.N., Pettit, M.E., Preece, R.C., Switsur, V.R., Whiteman, C.A. \& Zhou, L.P. 1999: Late and Middle Pleistocene deposits Somersham, Cambridgeshire, U.K: a model for reconstructing fluvial/estuarine depositional environments. Quaternary Science Reviews 18, 1247-1314.

Wingfield, R.T.R. 1990: The origin of major incisions within Pleistocene deposits of the North Sea. Marine Geology 91, 31-52. 